\title{
Iron(III) Porphyrin Covalently Supported onto Magnetic Amino-Functionalized Nanospheres as Catalyst for Hydrocarbon and Herbicide Oxidations
}

\author{
Joicy S. dos Santos, ${ }^{a}$ André L. Faria,${ }^{a}$ Patrícia M. da Silva Amorin, ${ }^{a}$ \\ Franco M. La Luna, ${ }^{a}$ Kely L. Caiado, ${ }^{b}$ Débora O. C. e Silva, ${ }^{c}$ \\ Patrícia P. C. Sartoratto ${ }^{b}$ and Marilda D. Assis* ${ }^{*, a}$
}

\author{
${ }^{a}$ Departamento de Química, Faculdade de Filosofia, Ciências e Letras de Ribeirão Preto, \\ Universidade de São Paulo, Av. Bandeirantes, 3900, 14040-901 Ribeirão Preto-SP, Brazil

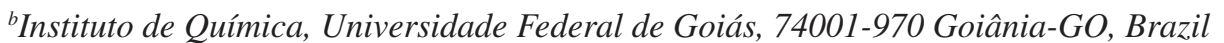 \\ ${ }^{c}$ Laboratório de Microscopia Eletrônica, Instituto de Ciências Biológicas, \\ Universidade de Brasília, 70910-900 Brasília-DF, Brazil
}

Este trabalho descreve a imobilização por ligação covalente de uma ferroporfirina, cloreto de 5,10,15,20-tetraquis(pentafluorofenil)porfirinaferro(III) (FeTFPP), sobre nanoesferas de maguemita cobertas com sílica aminofuncionalizada. $\mathrm{O}$ material resultante (nomeado $\gamma-\mathrm{Fe}_{2} \mathrm{O}_{3} / \mathrm{SiO}_{2}-\mathrm{NHFeP}$ ) foi caracterizado por espectroscopia no infravermelho por refletância difusa (DRIFTS) e espectroscopia de absorção UV-Vis. A atividade catalítica desta ferroporfirina magnética foi investigada em reações de oxidação de hidrocarbonetos (estireno, (Z)-cicloocteno e $R$-(+)-limoneno) e de um herbicida (simazina), utilizando-se peróxido de hidrogênio ou ácido metacloroperbenzóico. Os produtos das reações de oxidação de hidrocarbonetos e simazina foram analisados por cromatografia em fase gasosa (GC) e cromatografia líquida de alta resolução (HPLC), respectivamente. Este sistema catalítico provou ser eficiente e seletivo na oxidação dos hidrocarbonetos, levando a altos rendimentos na oxidação do estireno $(89 \%)$, cicloocteno $(71 \%) \mathrm{e}$ (+)-limoneno (86\%). Na oxidação da simazina catalisada pelo $\gamma$ - $\mathrm{Fe}_{2} \mathrm{O}_{3} / \mathrm{SiO}_{2}-\mathrm{NHFeP}$, obteve-se $100 \%$ de seletividade para um produto desalogenado (OEAT), enquanto a mesma reação em meio homogêneo levou à formação de diversos produtos de oxidação. O catalisador pode ser facilmente recuperado pela aplicação de um campo magnético externo e lavado ao final das reações. Nos estudos de reutilização do catalisador para a oxidação do (+)-limoneno, a atividade catalítica foi mantida em $90 \%$, mesmo após 10 reações consecutivas.

This work describes the covalent immobilization of an ironporphyrin, 5,10,15,20tetrakis(pentafluorophenyl)porphyrin iron(III) chloride (FeTFPP), onto maghemite/silica magnetic nanospheres covered with aminofunctionalized silica. The resulting material $\left(\gamma-\mathrm{Fe}_{2} \mathrm{O}_{3} / \mathrm{SiO}_{2}-\right.$ $\mathrm{NHFeP}$ ) was characterized by diffuse reflectance infrared spectroscopy (DRIFTS) and UV-Vis absorption spectroscopy. The catalytic activity of this magnetic ironporphyrin was investigated in the oxidation of hydrocarbons (styrene, (Z)-cyclooctene and $R$-(+)-limonene) and an herbicide (simazine) by hydrogen peroxide or 3-chloroperoxybenzoic acid. Hydrocarbon and simazine oxidation reaction products were analyzed by gas chromatography (GC) and high performance liquid chromatography (HPLC), respectively. This catalytic system proved to be efficient and selective for hydrocarbon oxidation, leading to high product yields from styrene (89\%), cyclooctene (71\%) and $R$-(+)-limonene (86\%). Simazine oxidation was attained with $100 \%$ selectivity for a dechlorinated product (OEAT), while several oxidation products were obtained for the same catalyst in homogeneous media. The catalyst can be easily recovered through application of an external magnetic field and washed after reaction. Catalyst reuse experiments for $R-(+)$-limonene oxidation have shown that the catalytic activity is kept at $90 \%$ after 10 consecutive reactions.

Keywords: magnetic nanospheres, magnetic ironporphyrin, hydrocarbon oxidation, limonene, simazine

*e-mail: mddassis@usp.br 


\section{Introduction}

Magnetic nanospheres have been the focus of many research areas because of their potential application in biochemistry, smart materials and catalysis. ${ }^{1,2}$ For catalytic purposes, functionalized magnetic nanoparticles have been pointed out as alternatives to conventional supports because they are promptly available and robust, not to mention that they confer stability to the catalyst.,4 Their magnetic properties provide a unique way for catalyst recovery and reuse since they can be separated from the reaction medium by application of a magnetic field. ${ }^{1-8}$ Several works have reported on the use of magnetic nanospheres in catalysis, either as catalyst or as support for a number of catalysts. ${ }^{1,4,8}$ Recently, researchers have studied the immobilization of a manganese porphyrin onto a magnetic polymer for cyclohexane hydroxylation, ${ }^{4}$ giving rise to a new class of supports for cytochrome P450 biomimetic models. The P450 are a class of enzymes responsible for countless oxidation reactions, ranging from steroid biosynthesis to xenobiotic metabolism. ${ }^{9}$ Synthetic metalloporphyrins (MePs) have been employed over the last three decades and are considered the best biomimetical models of these enzymes. ${ }^{10,11}$

Many MeP-based catalytic systems have been investigated for the oxidation of various substrates, especially alkene epoxidation and alkane hydroxylation. ${ }^{12-16}$ The best catalytic systems have also been utilized in the oxidation of drugs, herbicides and other substrates, with good efficiencies. ${ }^{17-20}$

The design and refinement of these bioinspired catalytic systems have progressed with the synthesis of MePs with increasing number of substituents in the porphyrin ring ${ }^{21}$ and the use of various oxidants. ${ }^{11}$ Although these refinements have resulted in more efficient and stable catalysts, their high cost still make their application difficult, even in fine chemistry. In order to overcome this drawback, immobilization of these catalysts onto solid supports has been proposed, aiming at their separation from the reaction medium, thereby enabling its reuse. Many materials have been employed as MePs supports, ${ }^{22-25}$ some of which have afforded good turnovers in recycling reactions. Nevertheless, part of the solid catalyst is always lost during the separation and washing procedures. In this context, MeP immobilization onto magnetic nanospheres is an innovative approach since it allows for combination of the biomimetic properties of MePs with the easy recovery of the supported complex by simple application of an external magnetic field originated from a small, commercially available, inexpensive magnetic stirring bar, commonly utilized in research laboratories. Anchoring of metalloporphyrins onto magnetic nanospheres offers the advantage of increasing catalyst stability, enhancing selectivity and even reducing costs, because these catalysts are very expensive. ${ }^{4,22}$

In this sense, as part of our ongoing studies on bioinspired catalysts, in this work, a MeP, namely 5,10,15,20-tetrakis(pentafluorophenyl)porphyrin iron(III) chloride (FeTFPP, Figure 1), was immobilized onto the surface of maghemite magnetic nanospheres covered with aminofunctionalized silica by covalent binding. The resulting material was used as catalyst for alkene (styrene, cyclooctene and $R$-(+)-limonene) and simazine (an herbicide) oxidations by hydrogen peroxide or 3-chloroperoxybenzoic acid.

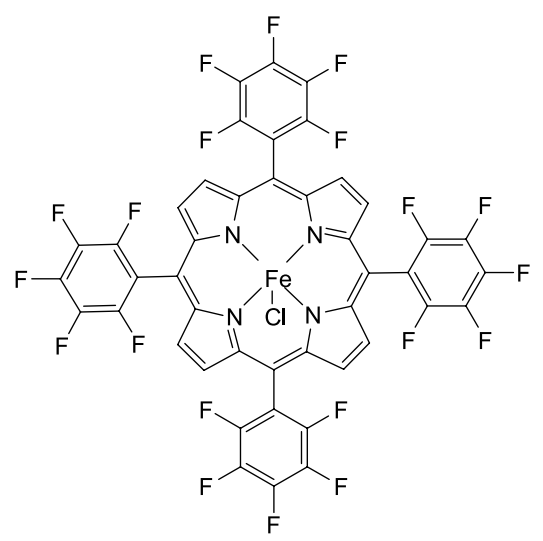

Figure 1. Chemical structure of 5,10,15,20-tetrakis(pentafluorophenyl) porphyrin iron(III) chloride (FeTFPP).

\section{Experimental}

\section{Materials}

All reagents were commercially available and of analytical grade purity unless otherwise stated. Hydrogen peroxide $(30 \%$ wt., provided by Fluka) was stored at $5{ }^{\circ} \mathrm{C}$ and titrated periodically. 3-Chloroperoxybenzoic acid ( $m$-CPBA, 70\%) was purchased from Acros Organics. The hydrocarbons (Z)-cyclooctene, styrene and $R-(+)$-limonene (Acros) were purified on a short activated basic alumina column (Merck) immediately before use. Simazine (CEET, 99\%) was acquired from Supelco. The free-base porphyrin 5,10,15,20-tetrakis(pentafluorophenyl)porphyrin was obtained from MidCentury. Metal insertion into this free base was carried out by applying the method of Adler et al. ${ }^{26}$ $\mathrm{FeCl}_{2} \cdot 4 \mathrm{H}_{2} \mathrm{O}$ and $\mathrm{FeCl}_{3} \cdot 6 \mathrm{H}_{2} \mathrm{O}$ were supplied by Fluka and Acros, respectively. Ammonium hydroxide solution was provided by Nuclear. Tetraethoxysilane (TEOS) and (3-aminopropyl)trimethoxysilane (APTS) were purchased from Acros. 
Synthesis and characterization of the ironporphyrin immobilized onto magnetic nanospheres covered with aminopropylsilica, $\gamma-\mathrm{Fe}_{2} \mathrm{O}_{3} / \mathrm{SiO}_{2}-\mathrm{NHFeP}$

The magnetic nanoparticles covered with amino functionalized silica, $\gamma-\mathrm{Fe}_{2} \mathrm{O}_{3} / \mathrm{SiO}_{2}-\mathrm{NH}_{2}$, were synthesized as previously described ${ }^{5,6}$ by an adaptation of the Stöber method, ${ }^{27}$ and characterized by transmission electron microscopy (TEM).

The catalyst $\gamma-\mathrm{Fe}_{2} \mathrm{O}_{3} / \mathrm{SiO}_{2}-\mathrm{NHFeP}$ was prepared by mixing $400 \mathrm{mg}$ of nanospheres with a solution containing $5.04 \mathrm{mg}$ of 5,10,15,20-tetrakis(pentafluorphenylporphyrin) iron(III) chloride in $5 \mathrm{~mL}$ ethyleneglycol. The mixture was maintained under reflux with $\mathrm{N}_{2}$ bubbling at $110{ }^{\circ} \mathrm{C}$ for $24 \mathrm{~h}$. The solid was isolated by application of a magnetic field and was submitted to Soxhlet extraction with dichloromethane for $24 \mathrm{~h}$ and methanol for another $24 \mathrm{~h}$ to extract the ironporphyrin that was just adsorbed onto the support or was immobilized by coordinative binding through the iron center, leaving only the covalently attached ironporphyrin on the support. The amount of FeP that was leached from the solid was determined in the extraction solvents by UV-Vis spectroscopy, using the absorbance of the Soret band characteristic of this FeP $(420 \mathrm{~nm})$. The composite was characterized by diffuse reflectance infrared spectroscopy (DRIFTS) and UV-Vis spectroscopy.

\section{Equipment}

Diffuse reflectance spectra (DRIFTS) were obtained on a Bomem MB 100 spectrometer equipped with a DRIFT collector accessory, using the system resolution set at $4 \mathrm{~cm}^{-1}$ and a total 128 scans, with the samples dispersed in $\mathrm{KBr}$ pellets (1\%). UV-Vis analyses were performed on a Hewlett-Packard 8452 diode array spectrophotometer using a quartz cell with optical path of $1 \mathrm{~cm}$. The transmission electron microscopy (TEM) images were obtained using a JEOL-1011 microscope at $80 \mathrm{keV}$. Diffuse reflectance (DR UV-Vis) spectra were analyzed on Ocean Optics USB 4000 equipment using an optic fiber vertically positioned $1.5 \mathrm{~cm}$ from the sample. Atomic absorption analyses were performed on a Perkin Elmer spectrophotometer (model AAnalyst 200).

Gas chromatographic (GC) analyses were conducted on a Shimadzu chromatograph (model GC-2010) equipped with an AOC-20i auto-injector, flame ionization detector and capillary column RTX-Wax (dimensions of $30 \mathrm{~m} \times 0.320 \mathrm{~mm} \times 0.25 \mu \mathrm{m}$ ) from Agilent Technologies. Nitrogen was used as the carrier gas.

High performance liquid chromatographic (HPLC) analyses were accomplished on a Shimadzu liquid chromatograph equipped with two LC-10AS solvent pumps, an SPD-M 10 A VP spectrophotometric detector $(\lambda=230 \mathrm{~nm})$ coupled to a CTO-10 A VP column oven, a CL-10A VP system controller and an injector with a $20 \mu \mathrm{L}$ loop. The device was connected to a diode array spectrophotometer.

\section{Oxidation reactions}

Oxidation reactions were accomplished in $3 \mathrm{~mL}$ vials with a screw cap. The initially employed catalyst/ oxidant/substrate molar ratio was of 1:500:1000, achieved through addition of $5 \times 10^{-5} \mathrm{~mol}$ substrate, $2.5 \times 10^{-5} \mathrm{~mol}$ oxidant and a mass of the solid material enough to transfer $5 \times 10^{-8} \mathrm{~mol} \mathrm{FeP}$ catalyst to the vial. Acetonitrile (ACN) was employed as solvent, and the final volume was completed to $1.5 \mathrm{~mL}$ with solvent. Reactions were maintained under mechanic stirring at room temperature. Catalyses were run using 3-chloroperoxybenzoic acid ( $m$-CPBA) or hydrogen peroxide $\left(\mathrm{H}_{2} \mathrm{O}_{2}\right)$ as oxidants. Styrene, $(\mathrm{Z})$-cyclooctene and $R$-(+)-limonene were employed as substrates. For the reuse studies, the catalyst was separated from the reaction medium by application of a magnetic field using a small magnetic bar. After isolation, the solid catalyst was washed with acetonitrile, separated from the solvent as described above and dried in air before addition of new amounts of substrate and oxidant.

Hydrocarbon oxidation products were analyzed by gas chromatography (GC). The yields are based on the added oxidant and determined after $4 \mathrm{~h}$ reaction, using bromobenzene as internal standard. Control reactions were carried out using the magnetic nanoparticles without catalyst, $\gamma-\mathrm{Fe}_{2} \mathrm{O}_{3} / \mathrm{SiO}_{2}-\mathrm{NH}_{2}$. No products were detected in these cases.

Simazine oxidation was performed using a catalyst/ oxidant/substrate molar ratio of 1:60:60, achieved by addition of $4 \times 10^{-6} \mathrm{~mol}$ substrate, $7.5 \times 10^{-5} \mathrm{~mol}$ oxidant and $2.5 \times 10^{-7} \mathrm{~mol}$ metalloporphyrin to the reaction vessel. A mixture of methanol and dichloromethane 1:1 (v/v) was employed as solvent. The final volume was completed to $1.5 \mathrm{~mL}$ with solvent, and the reactions were kept under mechanic stirring for $4 \mathrm{~h}$ at room temperature. Reactions were run by using 3-chloroperoxybenzoic acid ( $m$-CPBA) or hydrogen peroxide $\left(\mathrm{H}_{2} \mathrm{O}_{2}\right)$ as oxidant. When $m$-CPBA was employed, the unreacted oxidant was removed from the reaction medium before product analysis, via extraction with an aqueous (10\%) $\mathrm{Na}_{2} \mathrm{SO}_{4}$ solution. Separation of simazine from its oxidation products was accomplished by HPLC and conducted in $\mathrm{C}_{18}$ LiChrospher column (Merck) with $5 \mu \mathrm{m}$ particle size $(125 \times 4 \mathrm{~mm})$. The mobile phase consisted of methanol and $0.1 \%$ trifluoroacetic acid (TFA), 
followed by a gradient ranging from MeOH/TFA 5:95 (v/v) to MeOH/TFA 50:50, at a flow rate of $1 \mathrm{~mL} \mathrm{~min}{ }^{-1}$. The total elution time was $35 \mathrm{~min}$. The mobile phase was purged with helium. Reaction products were analyzed by comparison of their retention times with standard solutions of the authentic metabolites. Product yields or conversions were determined from calibration curves and were based on the added herbicide. Fractions were collected for identification of unknown products by mass spectrometry and comparison with similar products previously identified for other catalytic systems. ${ }^{28}$

\section{Results and Discussion}

Synthesis and characterization of the solid catalyst, $\gamma-\mathrm{Fe}_{2} \mathrm{O}_{3} / \mathrm{SiO}_{2}-\mathrm{NHFeP}$

FeTFPP (Figure 1) is a second-generation ironporphyrin that is commercially available and has been reported to be a good catalyst for hydrocarbon, drug and herbicide oxidation. ${ }^{12-20}$ The modification of phenyl groups with electron-withdrawing or bulky substituents has been found to enhance MeP catalytic activity by creating a cage around the metal-oxo, thus avoiding catalyst self-degradation or formation of inactive $\mu$-oxo dimers. ${ }^{29,30}$ Bearing these advantages in mind, this metalloporphyrin was selected for binding onto magnetic amino-substituted nanoparticles. Besides these advantageous properties, this porphyrin also contains para-fluorine phenyl substituents that enable its covalent attachment to the amino group of the functionalized nanospheres. This approach results in a catalyst that is strongly attached to the solid support and cannot be leached during oxidation reactions in any solvent, ranging from water to polar organic ones, ${ }^{31}$ while $100 \%$ catalyst recovery can be obtained after the reaction.

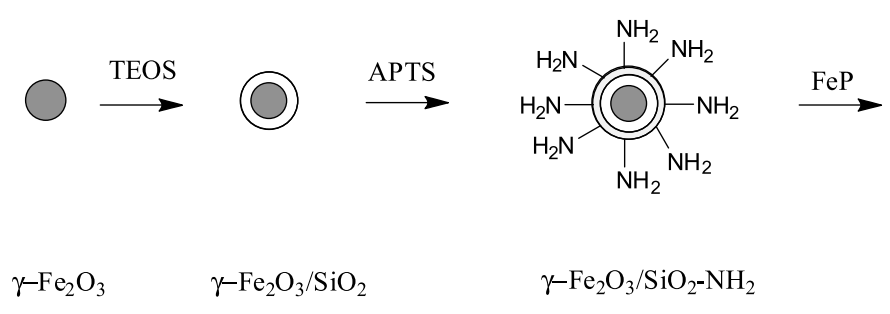

(a)
Figure 2 depicts the scheme relative to the preparation of $\gamma-\mathrm{Fe}_{2} \mathrm{O}_{3} / \mathrm{SiO}_{2}-\mathrm{NHFeP}$. Steps a and $\mathrm{b}$ have been previously described ${ }^{5,6}$ and involve the coverage of the maghemite nanoparticles with silica (Figure 2, a), and its functionalization with the amine group (Figure 2, b) following covalent attachment of the ironporphyrin through nucleophilic aromatic substitution of the para-fluorine atoms in the pentafluorophenyl group, as described for immobilization of this ironporphyrin onto other aminofunctionalized materials $\mathrm{s}^{32-34}$ (Figure 2, c).

The amount of iron in $\gamma-\mathrm{Fe}_{2} \mathrm{O}_{3} / \mathrm{SiO}_{2}-\mathrm{NH}_{2}$ dry nanospheres was determined to be $5.18 \times 10^{-4} \mathrm{~mol} \mathrm{Fe} \mathrm{per} \mathrm{g}$ of composite, as evidenced by atomic absorption spectrophotometry. The average diameter of the maghemite nanoparticles inside the silica nanospheres was $10 \mathrm{~nm}$ as calculated from the X-ray diffraction data of the $\gamma-\mathrm{Fe}_{2} \mathrm{O}_{3}$ nanoparticles (not shown). Figure 3 shows TEM image of the $\gamma-\mathrm{Fe}_{2} \mathrm{O}_{3} / \mathrm{SiO}_{2}-\mathrm{NH}_{2}$ nanospheres. The morphology of the nanospheres is uniform with the presence of spherical maghemite nanoparticles with average diameter of $318 \mathrm{~nm}$. The material consists of multicore maghemite-silica particles with a thick silica shell covered by a thin amino-functionalized silica layer, as previously described. ${ }^{5}$

The content of the immobilized ironporphyrin (loading) in the nanospheres was determined by UV-Vis spectroscopy from the absorbance of the FeTFPP Soret band at $420 \mathrm{~nm}^{29}$ These measurements were carried out in the supernatant obtained from the Soxhlet extractions and provided a value of $11 \mathrm{mg}$ ironporphyrin per $\mathrm{g}$ of magnetic nanospheres or $1 \times 10^{-2} \mathrm{mmol}$ ironporphyrin per $\mathrm{g}$ of nanospheres ( $84 \%$ of the amount of FeP that was initially employed). The solid catalyst was also characterized by DRIFTS and DR UV-Vis spectroscopy, which showed a band in $420 \mathrm{~nm}$, confirming the $\mathrm{MeP}$ presence in the material.

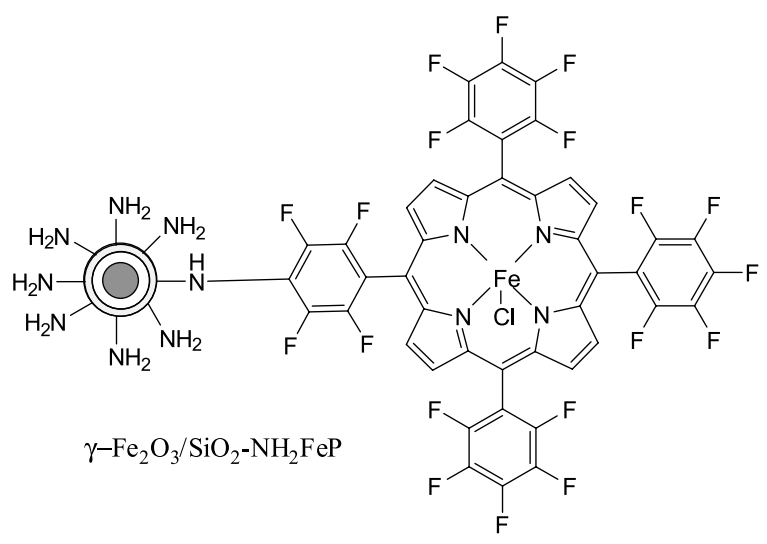

(c) 

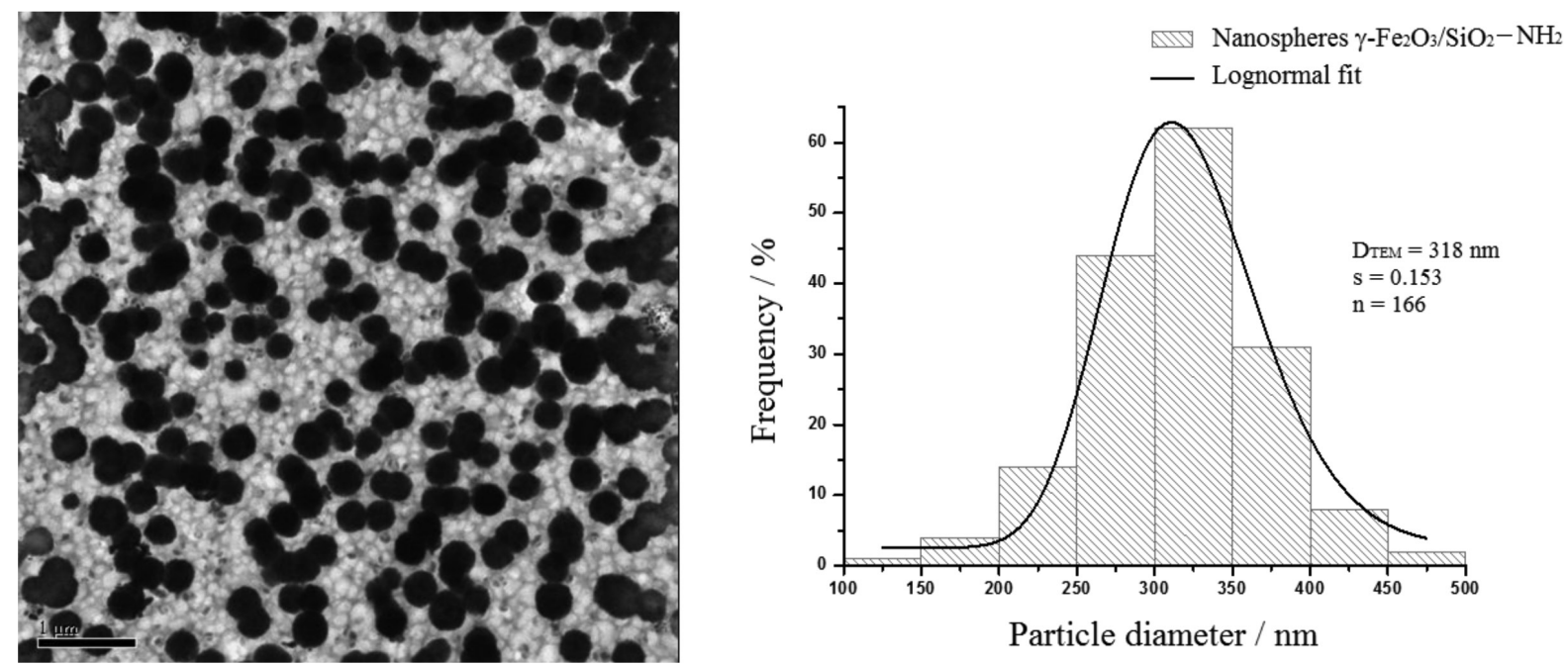

Figure 3. TEM image of $\gamma-\mathrm{Fe}_{2} \mathrm{O}_{3} / \mathrm{SiO}_{2}-\mathrm{NH}_{2}$ nanospheres and particle size histogram ( $\mathrm{D}_{\text {TEM }}$ : average diameter).

Figure 4 represents the DRIFTS spectra of the $\gamma-\mathrm{Fe}_{2} \mathrm{O}_{3} / \mathrm{SiO}_{2}-\mathrm{NH}_{2}$ and $\gamma-\mathrm{Fe}_{2} \mathrm{O}_{3} / \mathrm{SiO}_{2}-\mathrm{NHFeP}$ nanospheres. The spectra were initially registered with the material diluted in $\mathrm{KBr}$ (as usual), but no changes were observed when both spectra were compared. As an attempt to identify some vibrational modes associated with the bonds existing in the complex, the IR measurements were accomplished using the pure solid without any dilution with KBr. However, even in this pure sample it was not possible to observe the IR bands associated with the ironporphyrin complex due to the low FeTFPP loading in this material. The bands observed at 520 and $610 \mathrm{~cm}^{-1}$ can be attributed to $\mathrm{Fe}-\mathrm{O}$ vibrational modes of the iron oxide. ${ }^{34}$ The broad band in the range of $3500-3000 \mathrm{~cm}^{-1}$ is due to $\mathrm{OH}$ stretching of free water molecules and the silanol remaining groups $(\mathrm{SiO}-\mathrm{H})$. The absorptions at 800 and $960 \mathrm{~cm}^{-1}$ can be assigned to $\mathrm{Si}-\mathrm{O}-\mathrm{Si}$ stretching and $\mathrm{Si}-\mathrm{OH}$ stretching, respectively. Three other

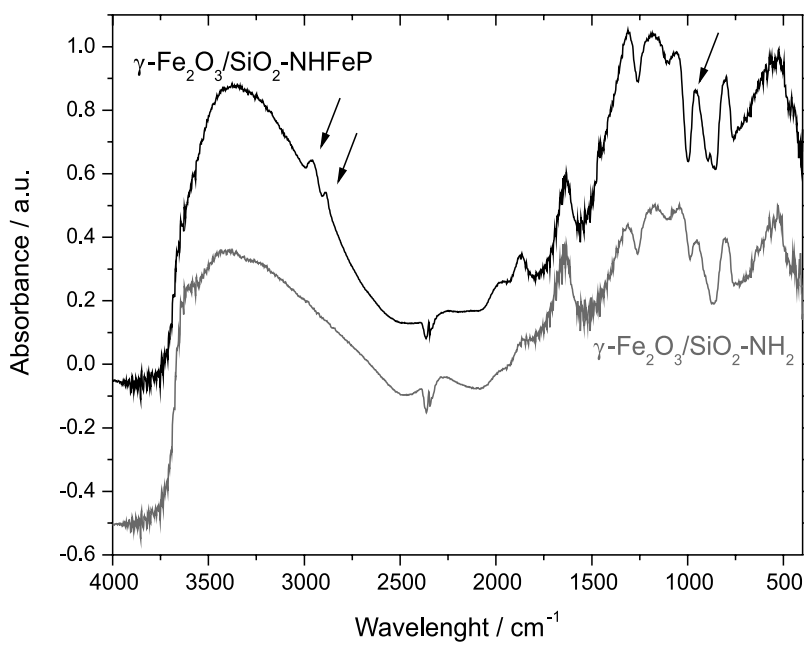

Figure 4. DRIFTS spectra of the $\gamma-\mathrm{Fe}_{2} \mathrm{O}_{3} / \mathrm{SiO}_{2}-\mathrm{NH}_{2}$ and $\gamma-\mathrm{Fe}_{2} \mathrm{O}_{3} / \mathrm{SiO}_{2}-$ NHFeP nanospheres. bands associated with $\mathrm{Si}-\mathrm{O}-\mathrm{Si}$ asymmetric stretching can be seen at 1058, 1184 and $1309 \mathrm{~cm}^{-1}$. 35,36 Figure 4 also reveals weak bands at 2962 and $2890 \mathrm{~cm}^{-1}$, which can be ascribed to vibrational modes due to aliphatic $\left(-\mathrm{CH}_{2}\right)$ stretching of the propyl chain from APTS, proving that functionalization of the support was indeed achieved.

The catalytic activity of the studied system was initially investigated for the oxidation of (Z)-cyclooctene, styrene and $R$-(+)-limonene. Either $\mathrm{H}_{2} \mathrm{O}_{2}$ or $m$-CPBA was used as oxidant. Results were measured in terms of product yields based on the oxidant. Hydrogen peroxide was employed for the oxidation of alkenes because it is considered a "clean oxidant" since it produces water as the only side-product. $m$-CPBA is a stable peroxyacid and is soluble in a variety of commonly used organic solvents, usually culminating in high epoxidation yields. ${ }^{37}$ The advantage of using alkylhydroperoxides is that they have excellent solubility in many organic solvents.

(Z)-Cyclooctene is a diagnostic substrate for all new catalytic systems involving metalloporphyrins since it is easily oxidized and generally produces the corresponding epoxide as the sole product. ${ }^{31,38}$ Table 1 lists the product yields from cyclooctene oxidation by $m$-CPBA and $\mathrm{H}_{2} \mathrm{O}_{2}$ catalyzed by the supported FeTFPP prepared herein. Initially, the oxidation reactions were accomplished using $5.0 \times 10^{-8} \mathrm{~mol}$ catalyst, $2.5 \times 10^{-5} \mathrm{~mol}$ oxidant and $5.0 \times 10^{-4} \mathrm{~mol}$ substrate, corresponding to a catalyst/oxidant/substrate molar ratio of 1:500:10000. To compare and optimize the catalytic conditions, a molar ratio of 1:250:5000 was also tested. The reaction conducted at the molar ratio of 1:250:5000 (catalyst/oxidant/substrate) rendered higher cyclooctene oxide yields ( $71 \%$ for reactions with $m$-CPBA).

Product yields are highly dependent on the oxidant, the best one being $m$-CPBA (Table 1, entries 2 and 4). 
Table 1. Cyclooctene oxidation by $m$-CPBA and $\mathrm{H}_{2} \mathrm{O}_{2}$ catalyzed by $\gamma-\mathrm{Fe}_{2} \mathrm{O}_{3} / \mathrm{SiO}_{2}-\mathrm{NHFeP}$, in acetonitrile medium, after $24 \mathrm{~h}$ reaction

\begin{tabular}{lccc}
\hline Entry & Molar ratio $^{\mathrm{a}}$ & Oxidant & $\begin{array}{c}\text { Cyclooctene oxide } \\
\text { yield }^{\mathrm{b}} / \%\end{array}$ \\
\hline 1 & $1: 250: 5000$ & $\mathrm{H}_{2} \mathrm{O}_{2}$ & $\mathrm{Nd}$ \\
2 & $1: 250: 5000$ & $m$-CPBA & 71 \\
3 & $1: 500: 10000$ & $\mathrm{H}_{2} \mathrm{O}_{2}$ & $\mathrm{Nd}$ \\
4 & $1: 500: 10000$ & $m-\mathrm{CPBA}$ & 48 \\
\hline
\end{tabular}

${ }^{\mathrm{a}}$ Molar ratio: catalyst/oxidant/substrate; ${ }^{\mathrm{b}} 5.0 \times 10^{-8} \mathrm{~mol} \mathrm{FeTFPP}$; Nd: not detected; control reactions: no products detected.

No product was detected for reactions oxidized by $\mathrm{H}_{2} \mathrm{O}_{2}$, which can be explained by the catalyzed dismutation of this oxidant in the presence of metal complexes and/or ferromagnetic nanoparticles. ${ }^{30}$

Styrene oxidation generally leads to benzaldehyde, styrene oxide and phenylacetaldehyde as products, which are used as intermediates for the synthesis of fine chemicals as well as for production of fragrances, pharmaceuticals and agrochemicals. ${ }^{4,6}$ This hydrocarbon is extensively studied because it can generate different products depending on the reaction conditions. ${ }^{38}$ This special feature can be exploited so that a better understanding of the reaction mechanisms involving metalloporphyrins can be obtained.

The results from styrene oxidation catalyzed by $\gamma-\mathrm{Fe}_{2} \mathrm{O}_{3} / \mathrm{SiO}_{2}-\mathrm{NHFeP}$ are summarized in Table 2 for three reaction cycles using the same catalyst batch.

The catalyst $\gamma-\mathrm{Fe}_{2} \mathrm{O}_{3} / \mathrm{SiO}_{2}-\mathrm{NHFeP}$ efficiently promoted styrene oxidation by $m$-CPBA, reaching $89 \%$ total yield in the first reaction (Table 2, entry 1). Two products were obtained in this condition, phenylacetaldehyde (18\%) and styrene oxide, the major product (71\%). No benzaldehyde was produced. Control experiments using styrene oxide as substrate under the same reaction conditions showed that phenylacetaldehyde is not formed from the rearrangement of styrene oxide or from the rearrangement that could occur in the chromatograph injector. In fact, Groves and Mayer ${ }^{39}$ proposed a mechanism accounting for the parallel formation of styrene oxide and phenylacetaldehyde in systems involving metalloporphyrins. Scheme 1 displays an adapted scheme to explain the results obtained in the present study. ${ }^{40}$
In this scheme, an asymmetric transition that generates the epoxide (path $a$ ) or phenylacetaldehyde (path $b$ ) is represented. The latter is analogous to the well-established NIH rearrangement. ${ }^{41}$ Moreover, phenylacetaldehyde formation is related to the reactivity of the intermediate species (activated complex, Scheme 1). In other words, the lower is the reactivity, the longer is the lifetime and the higher is the probability of hydrogen rearrangement. This should lead to phenylacetaldehyde production (path b) and explains why yields for the latter product are lower as compared to styrene epoxide yields. Because the FeP is anchored onto the magnetic nanospheres, the steric effect of the support must disfavor the rearrangement that is necessary for phenylacetaldehyde production, as previously observed for the more robust $3^{\text {rd }}$ generation metalloporphyrins. ${ }^{42}$ As a result, high selectivity for the epoxide is achieved.

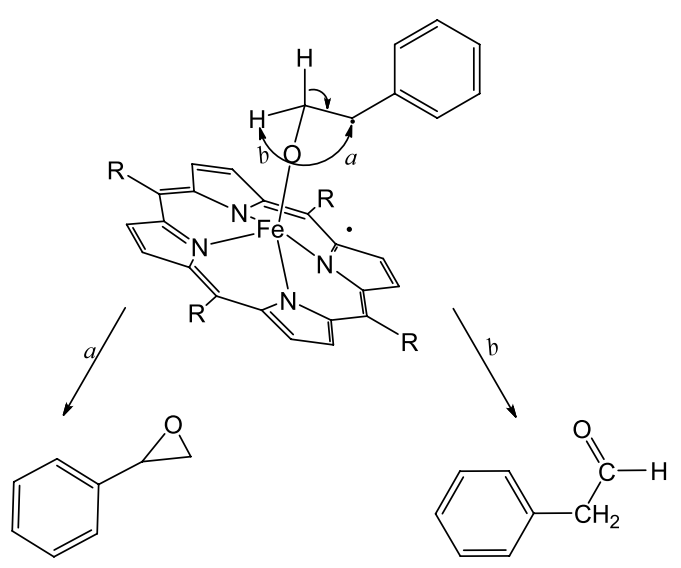

Scheme 1. Possible reaction paths for oxygen transfer from the ironporphyrin intermediate to styrene. Adapted from Groves et al. ${ }^{40}$

The magnetic catalyst was reused in three consecutive cycles for the oxidation of styrene (Table 2, entries 2 and 3), and the catalytic activity was maintained. The reuse reactions were facilitated by easy catalyst recovery through simple application of a magnetic field.

On the basis of the results obtained for (Z)-cyclooctene oxidation, the catalytic condition 1:250:5000 catalyst/ oxidant/substrate molar ratio was chosen for investigation of the $R-(+)$-limonene oxidation.

Table 2. Styrene oxidation by $m$-CPBA catalyzed by $\gamma-\mathrm{Fe}_{2} \mathrm{O}_{3} / \mathrm{SiO}_{2}-\mathrm{NHFeP}$, in acetonitrile medium, after $24 \mathrm{~h}$ of reaction

\begin{tabular}{lcccc}
\hline \multirow{2}{*}{ Entry } & \multirow{2}{*}{ Cycle } & \multicolumn{2}{c}{ Product yield $/ \%$} & Total yield $/ \%$ a \\
\cline { 3 - 4 } 1 & 1 & Phenylacetaldehyde & Styrene epoxide & 89 \\
2 & 2 & 18 & 71 & 74 \\
3
\end{tabular}

${ }^{a}$ Molar ratio: 1:500:10000 (catalyst/oxidant/substrate), $5.0 \times 10^{-8}$ mol FeTFPP; ${ }^{\mathrm{b}}$ control reactions: no products detected. 
Limonene is naturally found in orange peels, which is the main source of $R$-(+)-limonene, while the major source of S-(-)-limonene is lime peels. ${ }^{43}$ Oxygen-functionalized limonene derivatives (Figure 5) are important for food additives and for the pharmaceutical and agrochemical industries, ${ }^{43}$ the reason why the development of methods for the selective oxidation of this alkene has been the object of intense research. ${ }^{43-46}$

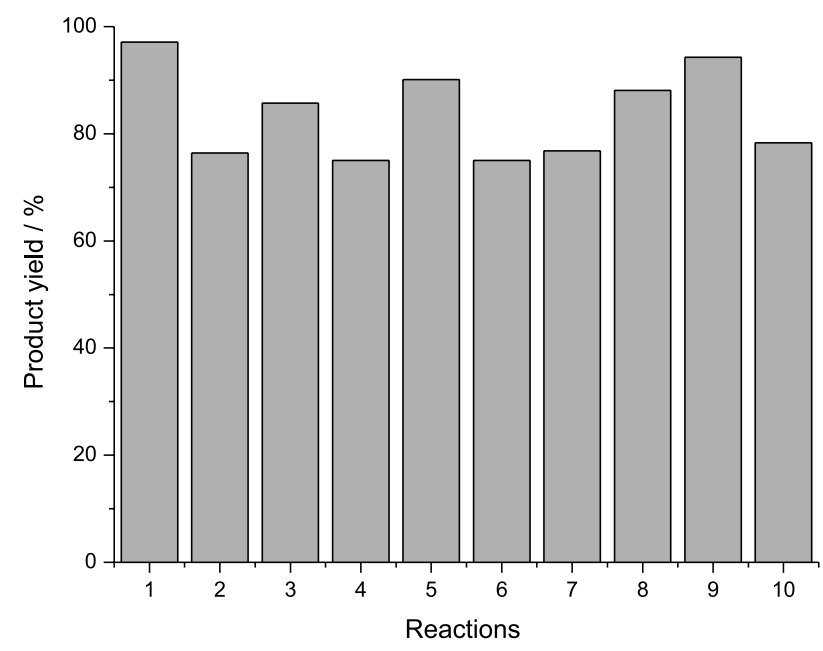

Figure 5. Oxidation of limonene by $m$-CPBA catalyzed by $\gamma-\mathrm{Fe}_{2} \mathrm{O}_{3} / \mathrm{SiO}_{2}-\mathrm{NHFeP}$ in acetonitrile (using a 1:250:5000 catalyst/oxidant/ substrate molar ratio) in 10 consecutive reactions.

Limonene oxidation was very effectively and selectively catalyzed by $\gamma-\mathrm{Fe}_{2} \mathrm{O}_{3} / \mathrm{SiO}_{2}-\mathrm{NHFeP}$, generating limonene oxide as the major product, as normally observed for limonene oxidation catalyzed by metalloporphyrins, ${ }^{44,46}$ together with traces of carveol and carvone (Table 3). Once again, oxidation reactions were largely dependent on the employed oxidant: $75 \%$ limonene conversion was reached after $4 \mathrm{~h}$ and $86 \%$ conversion was obtained after $24 \mathrm{~h}$ in reactions oxidized by $m$-CPBA. The reactions oxidized by $\mathrm{H}_{2} \mathrm{O}_{2}$ afforded poor results.

When alkyl peroxides, such as $m$-CPBA, are employed as oxidants, heterolytic cleavage of the $\mathrm{O}-\mathrm{O}$ bond is expected upon peroxide coordination to the metalloporphyrin central metal ion, giving rise to the active species oxoferryl porphyrin $\pi$-cation radical, $\mathrm{Fe}^{\mathrm{IV}}(\mathrm{O}) \mathrm{P}^{\bullet+}$ or oxomanganylporphyrin, $\mathrm{Mn}^{\mathrm{v}}(\mathrm{O}) \mathrm{P}$. However, the major problem regarding the use of $\mathrm{ROOH}$ with manganese and ironporphyrins is avoidance of the thermodynamically favored homolysis of the peroxide bond. O-O bond homolytic cleavage gives a less reactive intermediate $\left(\mathrm{Me}^{\mathrm{IV}}(\mathrm{OH}) \mathrm{P}\right)$ and generates an alkoxyl radical $\mathrm{RO}^{\circ}$, which is able to abstract a hydrogen atom from a saturated $\mathrm{C}-\mathrm{H}$ bond but is unable to produce epoxides from olefinic substrates. ${ }^{30}$ Because the $R$-(+)-limonene oxidation catalyzed by $\gamma-\mathrm{Fe}_{2} \mathrm{O}_{3} / \mathrm{SiO}_{2}-\mathrm{NHFeP}$ produced epoxide as the major product, it can be suggested that the high-valent metal oxo species, $\mathrm{Fe}^{\mathrm{IV}}(\mathrm{O}) \mathrm{P}^{\circ+}$, is the main catalytic species operating in this system. Low carveol and carvone yields can be explained by the difficulty in oxidizing the less reactive aliphatic $\mathrm{C}-\mathrm{H}$ bonds as compared to the easily oxidized $\mathrm{C}=\mathrm{C}$ leading to limonene epoxides.

The main advantage of the catalytic system studied herein is the facile catalyst recovery and washing, achieved by simply using a small magnetic bar to keep the catalyst inside the reaction vial, while the reaction medium or washing solvent is transferred to or from the vial. To evaluate this catalyst property and its stability in consecutive reactions, reuse experiments were conducted after isolation of the solid using a magnetic bar (Figure 5), its washing with acetonitrile (three times) and addition of new substrate and oxidant charges. Figure 5 shows that $90 \%$ of the catalytic activity is kept in 10 consecutive reactions, proving the stability of the ironporphyrin in these reaction conditions and its easy, $100 \%$ recovery at the end of each reaction.

Simazine (CEET, 6-chloro-2,4-ethylamino-1,3-5-triazine) is a herbicide belonging to the class of s-triazines, which is used in agriculture to control annual grasses and broadleaf weeds. It is mainly applied to maize, citrus, apples, sorghum and sugar cane crops. ${ }^{47,48}$ Simazine degrades relatively slowly in soil and is moderately persistent. ${ }^{49,50}$ Table 4 lists the chemical structures of simazine and its possible oxidation products and abbreviations. The nomenclature developed by Cook and Hütter ${ }^{51}$ and complemented elsewhere ${ }^{52}$ is employed herein for the

Table 3. $R$-(+)-limonene oxidation by $m$-CPBA and $\mathrm{H}_{2} \mathrm{O}_{2}$ catalyzed by $\gamma-\mathrm{Fe}_{2} \mathrm{O}_{3} / \mathrm{SiO}_{2}-\mathrm{NHFeP}$

\begin{tabular}{|c|c|c|c|c|c|c|}
\hline \multirow{2}{*}{ Entry } & \multirow{2}{*}{ Oxidant } & \multirow{2}{*}{ Time / h } & \multicolumn{3}{|c|}{ Product yield / \% } & \multirow{2}{*}{ Total yield / $\%$} \\
\hline & & & Epoxide $^{\mathrm{a}}$ /\% & Carvone & Carveol & \\
\hline 1 & $m$-СРBA & 4 & 75 & $\mathrm{Nd}$ & traces & 75 \\
\hline 3 & $\mathrm{H}_{2} \mathrm{O}_{2}$ & 4 & 2 & traces & traces & 2 \\
\hline 6 & $\mathrm{H}_{2} \mathrm{O}_{2}$ & 24 & 5 & traces & traces & 5 \\
\hline
\end{tabular}

${ }^{\mathrm{a}}$ Mixture of epoxides; Nd: not detected; solvent: acetonitrile; molar ratio: 1:250:5000 (catalyst/oxidant/substrate), $5.0 \times 10^{-8} \mathrm{~mol}$ FeTFPP; control reactions: no products obtained. 
Table 4. Chemical structure of simazine and its metabolites

\begin{tabular}{|c|c|c|c|c|}
\hline Abbreviation & Compound & $\mathrm{R}_{1}$ & $\mathrm{R}_{2}$ & $\mathrm{R}_{3}$ \\
\hline CEET & 6-chloro-2,4-diethylamino-2,4-diamino-1,3,5-triazine & $-\mathrm{Cl}$ & $-\mathrm{CH}_{2} \mathrm{CH}_{3}$ & $-\mathrm{CH}_{2} \mathrm{CH}_{3}$ \\
\hline CEAT & 6-chloro-2-ethylamino-4-amino-1,3,5-triazine & $-\mathrm{Cl}$ & $-\mathrm{CH}_{2} \mathrm{CH}_{3}$ & $-\mathrm{H}$ \\
\hline CAAT & 6-chloro-2,4-diamino-1,3,5-triazine & $-\mathrm{Cl}$ & $-\mathrm{H}$ & $-\mathrm{H}$ \\
\hline OAAT & 6-hydroxy-2,4-diamino-1,3,5-triazine & $-\mathrm{OH}$ & $-\mathrm{H}$ & $-\mathrm{H}$ \\
\hline OEAT & 6-hydroxy-2-ethylamino-4-amino-1,3,5-triazine & $-\mathrm{OH}$ & $-\mathrm{CH}_{2} \mathrm{CH}_{3}$ & $-\mathrm{H}$ \\
\hline OEET & 6-hydroxy-2,4-diethylamino-1,3,5-triazine & $-\mathrm{OH}$ & $-\mathrm{CH}_{2} \mathrm{CH}_{3}$ & $-\mathrm{CH}_{2} \mathrm{CH}_{3}$ \\
\hline
\end{tabular}

Table 5. Simazine conversion and relative product selectivity obtained in simazine oxidation by $m$-CPBA or $\mathrm{H}_{2} \mathrm{O}_{2}$, catalyzed by metalloporphyrins, in $\mathrm{DCM} / \mathrm{MeOH}$ and standard conditions, after $4 \mathrm{~h}$ of reaction

\begin{tabular}{|c|c|c|c|c|c|c|c|c|}
\hline \multirow{2}{*}{ Entry } & \multirow{2}{*}{ Catalyst } & \multirow{2}{*}{ Oxidant } & \multicolumn{5}{|c|}{ Relative selectivity / \% } & \multirow{2}{*}{$\begin{array}{c}\text { CEET }^{\mathrm{a}} \\
\text { conversion / \% }\end{array}$} \\
\hline & & & OEAT & CEAT & OEET & ODDT & ODET & \\
\hline 1 & $\mathrm{Fe}(\mathrm{TFPP}) \mathrm{Cl}$ & $m$-СРВA & 0 & 18 & 13 & 11 & 58 & 22 \\
\hline 3 & $\mathrm{Fe}(\mathrm{TFPP}) \mathrm{Cl}$ & $\mathrm{H}_{2} \mathrm{O}_{2}$ & - & 75 & - & 19 & 6 & $<1$ \\
\hline 4 & $\gamma-\mathrm{Fe}_{2} \mathrm{O}_{3} / \mathrm{SiO}_{2}-\mathrm{NHFeP}$ & $m$-СРBA & 100 & - & - & - & - & 12 \\
\hline 6 & $\gamma-\mathrm{Fe}_{2} \mathrm{O}_{3} / \mathrm{SiO}_{2}-\mathrm{NHFeP}$ & $\mathrm{H}_{2} \mathrm{O}_{2}$ & 100 & - & - & - & - & $<1$ \\
\hline
\end{tabular}

${ }^{a}$ Catalyst/oxidant/substrate molar ratio of 1:60:60.

identification of s-triazine compounds: A amino, $\mathrm{C}$ chloro, $\mathrm{D}$ acetamido, E ethylamino, $\mathrm{O}$ hydroxyl, I isopropyl and T for the triazine ring.

In order to extend the applicability of the studied magnetic catalytic system, it was also evaluated for the oxidation of the herbicide simazine by $\mathrm{H}_{2} \mathrm{O}_{2}$ or $m$-CPBA. Reactions were carried out in conditions previously optimized for other catalytic systems. ${ }^{28}$ Table 5 presents these results and also those obtained for the same catalyst in homogeneous system. Although the catalytic yields decreased for the $\gamma-\mathrm{Fe}_{2} \mathrm{O}_{3} / \mathrm{SiO}_{2}-\mathrm{NHFeP}$-catalyzed reactions as compared to those obtained with the same FeP in homogeneous medium, the solid catalyst led to a $100 \%$ selectivity, producing OEAT only (Table 4), while many different products were obtained in homogeneous medium (Table 5, entries 1-3). ${ }^{28}$ These results attest for another beneficial property of this support: the reaction proceeds through a mechanism involving one catalytic species only, whereas competitive catalytic species act when the catalyst is free in solution.

\section{Conclusions}

FeTFPP was successfully and strongly immobilized onto amino-functionalized magnetic nanospheres. This catalytic system proved to be highly efficient and selective for hydrocarbon oxidation, leading to high yields of products from styrene $(89 \%),(\mathrm{Z})$-cyclooctene $(71 \%)$ and $R$-(+)-limonene $(86 \%)$ oxidation using two oxidants. The high selectivity for epoxide suggests that the high valent metal-oxo intermediate $\left(\mathrm{Fe}^{\mathrm{IV}}(\mathrm{O}) \mathrm{P}^{\bullet+}\right)$ must be the main catalytic species involved in this system. Reuse experiments in the oxidation of $R$-(+)-limonene show that catalytic efficiency is kept after 10 consecutive reactions since the same high catalytic yields are achieved. The solid catalyst is easily recovered (100\%) and washed at the end of each reaction. The high applicability of this catalytic magnetic system has been also demonstrated for an inert substrate such as the herbicide simazine, giving a $100 \%$ selectivity for production of a dechlorinated product. This specificity for one oxidized product shows the great beneficial role of the support in determining the reaction mechanism. Remembering the chemical inertness of this herbicide, which is highly persistent in the environment, as well as the facility in isolating the catalyst for reuse, this catalytic system has great potential application in fine chemistry.

This magnetically separable material also eliminates the requirement of catalyst filtration after the reaction 
completion, which is an additional eco-friendly attribute of this synthetic protocol.

\section{Acknowledgments}

We thank Fundação de Amparo a Pesquisa do Estado de São Paulo (FAPESP), Conselho Nacional de Desenvolvimento Científico e Tecnológico (CNPq) and Coordenação de Aperfeiçoamento de Pessoal de Nível Superior (CAPES) for financial supports and Cynthia Maria de Campos Prado Manso for the article revision.

\section{References}

1. Yan, N.; Xiao, C.; Kou, Y.; Coord. Chem. Rev. 2010, 254, 1179.

2. Polshettiwar, V.; Baruwati, B.; Varma, R. S.; Green Chem. 2008, $11,127$.

3. Oppeneer, P. M.; Panchmatia, P. M.; Sanyal, B.; Eriksson, O.; Ali, M. E.; Surf. Sci. 2009, 84, 18.

4. Fu, B.; Yu, H. C.; Huang, J. W. ; Zhao, P.; Liu, J. ; Ji, L. N.; J. Mol. Catal. A: Chem. 2009, 298, 74.

5. Sartoratto, P. P. C.; Caiado, K. L.; Pedroza, R. C.; da Silva, S. W.; Morais, P. C.; J. Alloys Compd. 2007, 434-435, 650.

6. Almeida, M. P. S.; Caiado, K. L.; Sartoratto, P. P. C.; Cintra e Silva, D. O.; Pereira, A. R.; Morais, P. C.; J. Alloys Compd. 2010, 500, 149.

7. Kang, Y. S.; Risbud, S.; Rabolt, J. F.; Stroeve, P.; Chem. Mater. 1996, 8, 2209.

8. Sreedhar, B.; Kumar, A. S.; Reddy, P. S.; Tetrahedron Lett. 2010, $51,1891$.

9. de Montellano, P. R. O. In Cytochrome P-450: Structure, Mechanism and Biochemistry, $2^{\text {nd }}$ ed.; Plenum Publishers: New York, 2005, ch. 1.

10. Mansuy, D.; Ann. Pharm. Fr. 2011, 69, 62.

11. Mansuy, D.; Catal. Today 2008, 138, 2.

12. Groves, J. T.; Nemo, T. E.; Myers, R. S.; J. Am. Chem. Soc. 1979, 101, 1032.

13. Vinhado, F. S.; Gandini, M. E. F.; Iamamoto, Y.; Silva, A. M. G.; Simões, M. M. Q.; Neves, M. G. P. M. S.; Tomé, A. C.; Rebelo, S. L. H.; Pereira, A. M. V. M.; Cavaleiro, J. A. S.; J. Mol. Catal. A: Chem. 2005, 239, 138.

14. Solati, Z.; Hashemi, M. ; Ebrahimi, L.; Catal. Lett. 2011, 141, 163.

15. Huanga, G.; Luob, Z.; Xiang, F.; Caob, X.; Guob, Y.; Jiang, Y.; J. Mol. Catal. A: Chem. 2011, 340, 60.

16. Zhou, X.; Ji, H.; Chem. Eng. J. 2010, 156, 411.

17. Mac Leod, T. C. O.; Faria, A. L.; Barros, V. P.; Queiroz, M. E. C.; Assis, M. D.; J. Mol. Catal. A: Chem. 2008, 296, 54.

18. Rebelo, S. L. H; Pereira, M. M.; Monsanto, P. V.; Burrows, H. D.; J. Mol. Catal. A: Chem. 2009, 297,35.
19. Chauhan, S. M. S.; Kumari, P.; Tetrahedron Lett. 2007, 48, 5035 .

20. Gotardo, M. C. A. F.; Moraes, L. A. B.; Assis, M. D.; J. Agric. Food Chem. 2006, 12, 10011.

21. Gonsalves, A. M. D. A. R.; Pereira, M. M.; J. Mol. Catal. A: Chem. 1996, 113, 209.

22. Faria, A. L.; Mac Leod, T. C. O.; Assis, M. D.; Catal. Today 2008, 133-135, 863.

23. Mata, G.; Trujillano, R.; Vicente, M. A.; Korili, S. A.; Gil, A.; Belver, C.; Ciuffi, K. J.; Nassar, E. J.; Ricci, G. P.; Cestari, A.; Nakagaki, S.; Microporous Mesoporous Mater. 2009, 124, 218.

24. Machado, G. S.; Arízaga, G. G. C.; Wypych, F.; Nakagaki, S.; J. Catal. 2010, 274, 130.

25. Zucca, P.; Sollai, F.; Garau, A.; Rescigno, A.; Sanjust, E.; J. Mol. Catal. A: Chem. 2009, 306, 89.

26. Adler, D. A.; Longo, F. R.; Shergali, W.; Kampas, F.; Kim, J.; J. Inorg. Nucl. Chem. 1970, 32, 2443.

27. Stöber, W.; Fink, A.; Bohn, E.; J. Colloid Interface Sci. 1968 , $26,62$.

28. Santos, J. S.; Palaretti, V.; Faria, A. L.; Crevelin, E. J.; Moraes, L. A. B.; Assis, M. D.; Appl. Catal., A 2011, 408, 163.

29. Smith, K. M. In Porphyrins and Metalloporphyrins; Falk, J. E.; Smith, K. M., eds.; Elsevier Scientific Publishing Company: Amsterdam, Netherlands, 1975, ch. 1.

30. Meunier, B.; Robert, A.; Pratviel, G. In The Porphyrin Handbook, vol. 4; Kadish, K. M.; Smith, K. M.; Guilard, R., eds.; Academic Press: New York, 2000, ch. 31.

31. Assis, M. D.; Lindsay-Smith, J. R.; J. Chem. Soc., Perkin Trans. 2 1998, 2221.

32. Battioni, P.; Bartoli, J. F.; Mansuy, D.; Byun, Y. S.; Traylor, T. G.; J. Chem. Soc., Chem. Commun. 1992, 1051.

33. Doro, F. G.; Smith, J. R. L.; Ferreira, A. G.; Assis, M. D.; J. Mol. Catal. A: Chem. 2000, 164, 97.

34. Faria, A. L.; Airoldi, C.; Doro, F. G.; Fonseca, M. G.; Assis, M. D.; Appl. Catal. A 2004, 268, 217.

35. Tartaj, P.; Morales, M. P.; Veintemillas-Verdaguer, S.; GonzalezCarreño, T.; Serna, C. J.; J. Phys. D: Appl. Phys. 2003, 36, 182.

36. Sakka, S. In Handbook of Sol-Gel Science and Technology: Processing, Characterization and Aplications, vol. 2; Kluwer Academic Publisher: New York, 2005, ch 3.

37. Swern, D. In Organic Peroxides, vol. 2; Swern, V. D., ed.; Wiley-Interscience: New York-London, 1971; ch. 10.

38. Mahajan, S. S.; Sharma, M. M.; Sridha, T.; Ind. Eng. Chem. Res. 2005, 44, 1390.

39. Groves, J. T.; Myers, R. S.; J. Am. Chem. Soc. 1983, 105, 5791.

40. Groves, J. T.; Haushalter, R. C.; Nakamura, M.; Nemo, T. E.; Evans, B. J.; J. Am. Chem. Soc. 1981, 103, 2884.

41. Lindsay-Smith, J. R.; Shaw, B. A. J.; Jeffrey, A. M.; Jerina, D. M.; J. Chem. Soc., Perkin Trans. 2 1977, 1583.

42. Guedes, A. A.; Santos, A. C. M.; Assis, M. D.; Kinet. Catal. 2006, $47,555$. 
43. Cubillos, J. ; Vásquez, S. ; Correa, C. M. ; Appl. Catal., A 2010 , $373,57$.

44. Skrobot, F. C.; Valente, A. A.; Neves, G.; Rosa, I.; Rocha, J.; Cavaleiro, J. A. S.; J. Mol. Catal. A: Chem. 2003, 201, 211.

45. Oliveira, P.; Machado, A.; Ramos, A. M.; Fonseca, I.; Braz Fernandes, F.M.; Rego, A. M. B.; Vital, J.; Microporous Mesoporous Mater. 2009, 120, 432.

46. Brulé, E.; Miguel, Y. R.; Hii, K. K.; Tetrahedron 2004, 60, 5913.

47. Hauswirth, J. W.; Wetzel, L. T. J. In Triazine Herbicides: Risk Assessment; Ballantine, L. G.; McFarlland, J. E.; Hackett, D. S., eds; American Chemical Society: Washington DC, 1998, ch. 29.

48. Berns, A. E.; Bertmer, M.; Schaffer, A.; Meier, R. J.; Vereecken, H.; Lewandowski, H.; Eur. J. Soil Sci. 2007, 58, 882.
49. Chu, W.; Rao, Y.; Hui, W.Y.; J. Agric. Food Chem. 2009, 57, 6944.

50. Min, L.; Xiaomei, X.; J. Environ. Sci. 2008, 20, 195.

51. Cook, A. M.; Hütter, R.; J. Agric. Food Chem. 1981, 29, 1135.

52. Néulieu, S.; Kerhoas, L.; Einhorn, J.; Environ. Sci. Technol. 2000, 34, 430 .

Submitted: February 2, 2012

Published online: July 3, 2012

FAPESP has sponsored the publication of this article. 